\title{
MALLETE Y CINCEL: LAS RESONANCIAS MASÓNICAS DE HIJO DE LADRÓN
}

\author{
Pablo Concha Ferreccio \\ Universidad de Chile \\ Santiago, Chile \\ pabloconchas@gmail.com
}

RESUMEN / ABSTRACT

En este ensayo ofrezco una lectura de Hijo de ladrón desde su intertextualidad con el discurso masónico. Además de la novela editada y el mecanoescrito de 1950, el corpus integra actas de las tenidas masónicas en que Rojas participó, así como escritos inéditos del autor o de circulación restringida a iniciados. Mi tesis es que Rojas acude al simbolismo y a la antropología masónicos para repensar los conceptos de sujeto y comunidad en la novela. Desde la cita al ritual de iniciación y la espacialidad de la logia, reflexiono sobre una batería de símbolos que inciden fuertemente en la representación del derrotero vital de Aniceto y de los grupos humanos de los que forma parte. En el desarrollo discuto las relaciones de estos símbolos con otros de naturaleza anarquista.

Palabras Clave: Manuel Rojas, Hijo de ladrón, masonería, simbolismo, Bildungsroman.

\section{COMMON GAVEL AND CHISEL: THE MASONIC RESONANCES OF HIJO DE LADRÓN}

In this essay I offer a reading of Hijo de ladrón from its intertextuality with masonic discourse. In addition to the edited novel and the manuscript from 1950, the corpus includes records of the Masonic meetings in which Rojas participated, as well as unpublished and little known texts by the author. My thesis is that Rojas turns to Masonic symbolism and anthropology to rethink the concepts of subject and community in the novel. Considering the initiation ritual and the spatiality of the lodge, I reflect on a battery of symbols that strongly influence the representation of Aniceto's life path and the human groups which he is part of. In the development I discuss the relationships of these symbols with others of an anarchist nature. 
KEYWORDS: Manuel Rojas, Hijo de ladrón, freemasonry, simbolysm, Bildungsroman.

Recepción: 11/12/2020

Aprobación: 01/03/2021

\section{APERTURA DE LOS TRABAJOS ${ }^{1}$}

La filiación masónica de Manuel Rojas permanece como un capítulo de su biografía casi desconocido. Poco tiene que ver la masonería con el mundo marginal y el anarquismo que suelen tomarse por señas identificatorias del escritor, señas que han gobernado la mediación autobiográfica de su obra ( $c f$. Adriasola 32). Sin embargo, el extrañamiento que el dato masónico genera frente a nuestra imagen recibida de Rojas se relativiza al considerarlo en términos históricos. Varios escritores chilenos entre las décadas del veinte y del cincuenta fueron también masones (Pedro Prado, Alberto Romero, Carlos Préndez Saldías, Luis Enrique Délano, Armando Moock, entre otros), pues aquella red se trenzaba con las redes laborales, políticas y recreacionales de esa clase media funcionarial que fue caldo de cultivo del intelectual criollo. Habiendo accedido a estos círculos a partir de 1928, la entrada de Rojas a la logia "Germinación" № 81 es fruto de un proceso sociológico común en la época. La indagación del dato masónico contribuiría no solo al conocimiento de una zona poco explorada de su biografía (los años cuarenta, su vida como funcionario, escritor y hombre de letras), sino que además podría iluminar una faceta relegada de su proyecto literario e intelectual, una que difiere de las claves anarquista y popular-marginal ${ }^{2}$.

\footnotetext{
Agradezco a Pablo Faúndez Morán y a Alejandro Fielbaum los comentarios que hicieron a una versión previa de este texto; también a Jimena Castro, por una referencia bibliográfica clave, y a Wilfredo Tapia, por su generosidad en materia de hermetismo. Los errores que permanecen son míos. La redacción del escrito se ha desarrollado en el marco de la beca CONICYT-PFCHA/Doctorado Nacional/2019-21192077.

2 Para una propuesta de abordaje del dato masónico y un tratamiento de su dimensión biográfico-política, $c f$. Concha Ferreccio, "Manuel Rojas, masón: primeras entradas de lectura". El presente artículo tiene su antecedente en dos ponencias: “¿Hijo de masón? Manuel Rojas en la Gran Logia" (XV Jornadas de Estudiantes de Postgrado en Humanidades, Artes, Ciencias Sociales y Educación de la Universidad de Chile, 18-20 de diciembre, 2017) y "Mallete y cincel: sobre el ascendente masónico de Hijo de ladrón" (Seminario Manuel Rojas: literatura chilena reciente, 12-13 de diciembre, 2018).
} 
El presente artículo está dedicado a la segunda dimensión: calibrar el impacto o la implicación del dato masónico en la literatura de Manuel Rojas. Un hecho llamativo acicatea este abordaje, y es que esta participación -19431950 - se desarrolla en paralelo a la escritura de Hijo de ladrón-1945?-1951 (cf. Rojas, cit. en Concha [Edmundo] 39)-, cuyo primer mecanoescrito data de fines de 1950 y se titula Tiempo irremediable ${ }^{3}$. En los mismos años, Rojas vive un contacto permanente y estrecho con el simbolismo masónico: escribe discursos para su logia, accede a las lecturas que conforman la instrucción de la orden y oficia como orador, quien tiene a su cargo velar por la correcta interpretación de la tradición masónica (Martín 530); es decir, Rojas posee un manejo avanzado de su hermenéutica. Para este ensayo considero especialmente "Significado de la Iniciación", discurso de Rojas leído en tenida (reunión masónica) el 25 de mayo de 1945 y publicado en la Revista Masónica de Chile en mayo de 1946; y El libro del aprendiz. Manual de instrucción iniciática editado para el uso de los francmasones del primer grado (1894), escrito por el suizo-alemán Oswald Wirth y empleado e impreso por la Gran Logia de Chile al menos desde 1929. Sumo a este corpus el mecanoescrito de Tiempo irremediable de 1950 (en adelante, MC1950), que vuelve aún más reconocible el intertexto de la novela con los textos de raíz esotérica.

El interés de Rojas por las representaciones esotéricas es rastreable ya desde la década del diez, lo que no sorprende si se recuerda que el espiritismo, la teosofía y el ocultismo fueron prácticas culturales que entablaron diversas relaciones con las militancias ácratas (Grez 214-9). Entiendo el simbolismo masónico entonces como vehículo de un código cultural esotérico, un "corpus de saber" (Barthes, $S / Z$ 172) que la producción literaria rojiana moviliza ${ }^{4}$. Las lecturas psicoanalíticas que el escritor hace en la década del treinta suponen un robustecimiento indirecto de este código, pues marcan una comprensión del símbolo (arquetipo o imagen) como clave cultural y como insumo para la creación artística auténtica. La labor del escritor puede participar con el proceso social mediante la creación de símbolos que logren inscribirse en el inconsciente colectivo:

\footnotetext{
Me refiero a la escritura de lo que hoy reconocemos como la novela, pues la reunión del material, la concepción del proyecto y las primeras tentativas datan del segundo lustro de los años treinta ( $c f$. Rojas, "Algo sobre Hijo de ladrón" 366-71).

Los diferentes usos de este código a lo largo de la producción rojiana merecen estudio aparte.
} 
Estos arquetipos se transmiten en los pueblos por tradición oral, y aun aquellos que son una pura creación literaria, llegan a ellos en la misma forma. La creación literaria rebasa, debido a la fuerza de su genio, los reducidos moldes del pensamiento escrito y se derrama sobre los pueblos, cumpliendo así una de sus funciones más nobles y menos conseguidas: enriquecer al pueblo con imágenes que engrandezcan su alma elemental y profunda ("El espíritu revolucionario en nuestros pueblos" 78).

La premisa de este ensayo es que Rojas asume ese proyecto estético-político con Hijo de ladrón; su tesis, que el escritor toma prestados elementos del simbolismo y de la antropología masónicos para pensar los conceptos de sujeto y de comunidad en la novela. Estos símbolos provienen sobre todo del ritual de iniciación y de la enseñanza del primer grado (aprendiz), con presencia menor de la del segundo grado (compañero). Como se verá, la formación (Bildung) de Aniceto Hevia, adolescente argentino pobre que protagoniza la novela, es informada por el simbolismo masónico en momentos fundamentales de su desarrollo, mientras que este irrumpe además en la representación de la(s) comunidad(es) de las que hace parte el protagonista o que él mismo genera. El diálogo friccionado de este repertorio simbólico con elementos de una matriz más bien anarquista da cuenta del tensionado plexo ideológico de la novela, de su jalonado humanismo.

Antes de comenzar, se impone un breve comentario sobre hermenéutica masónica y los deslindes teórico-metodológicos que aquella motiva. El imaginario masónico está marcado por el mismo eclecticismo que caracteriza a la orden toda, pues esta se concibe como heredera de los cultos y de las sociedades iniciáticas más antiguas del mundo. Su amplio abanico iconográfico articula símbolos, emblemas, alegorías y leyendas recogidos de la religión del antiguo Egipto, el pitagorismo y la tradición iniciática de la antigua Grecia, la Biblia, la cábala hebrea, la alquimia, el neoplatonismo y la arquitectónica medievales, la orden rosacruz y la Revolución francesa (Sánchez Ferré 602, 65). Estos diferentes sistemas semióticos además se relacionan entre sí, pues símbolos de una tradición se vinculan por semejanza o analogía con símbolos de otra. La masonería toma sus mitos y símbolos principalmente de dos sistemas: el geométrico-arquitectónico, que hacen suyo los gremios constructores medievales, y el bíblico, sobre todo el Antiguo Testamento. La relación entre ambos da su sello a la masonería moderna que se funda en el siglo XVIII (cf. García Arranz, Simbolismo masónico 110, 141). 
La segunda característica de esta hermenéutica es que los símbolos se resignifican en cada grado masónico; es decir, un mismo símbolo admite distintos niveles de significación. Ello se relaciona estrechamente con el estatuto del símbolo a nivel doctrinario, pues este constituye la piedra angular de la pedagogía masónica. Los símbolos se articulan por excelencia en los rituales que sirven para marcar el progreso de un masón en la logia, su jerarquía; en el ritual de un grado superior el masón amplía la batería de símbolos que aprendió en el grado inferior y su conocimiento de aquellos símbolos a su vez se enriquece, ya que adoptan sentidos nuevos. Los rituales son el marco en que los sistemas semióticos y los niveles de significación convergen para dar sentido moral o espiritual a herramientas de trabajo (escuadra, compás, etc.) y otros objetos, espacios, experiencias y viajes simbólicos.

Producto de lo anterior, las interpretaciones masónicas son muy fluidas en pasar de un sistema a otro y/o de un nivel a otro. Jan Snoek ha dicho que la enseñanza que aporta el ritual al masón que lo protagoniza opera mediante un "método alusivo" (325). Cada símbolo es "explicado" por un encadenamiento de citas que lo implican, lo que -y esto es importante- no cierra su sentido ni sanciona un "significado verdadero". Por el contrario, se espera que el masón extraiga un sentido de este manojo de referencias a partir de aquellas que le parezcan más significativas. Aun cuando no es posible igualar la hermenéutica masónica con la hermenéutica literaria, resulta útil reconocer los sistemas y niveles mencionados, pues conforman la legalidad de una dinámica semiótica que puede encontrar asidero en el texto literario.

Con todo, si se aproxima la hermenéutica literaria a la hermenéutica masónica se corre el riesgo de ver indicios allí donde no los hay, de levantar interpretaciones que ignoran las estructuras de la significación literaria. Al enfrentar este problema, Eco propuso un criterio para discriminar entre un conjunto de semejanzas significativas y relevantes y otra serie de indicios sobreestimados (entre una interpretación y una sobreinterpretación): que los indicios formen una isotopía semántica continua, "conjunto redundante de categorías semánticas que hace posible una lectura uniforme" (Greimas cit. en Eco, "La sobreinterpretación" 74). Este principio es útil, pero Eco asume que la isotopía debe coincidir con el texto de cabo a rabo y en cada una de sus partes, que el grado y extensión de la uniformidad de la lectura debe ser total. A esta exigencia vale oponer la propuesta de Carlo Ginzburg, que subraya el potencial constelativo de indicios textuales juzgados como menores. El paradigma indicial renuncia a la pretensión de conocimiento sistemático, pero rescata una idea de totalidad de sentido que se dibuja desde ciertas "zonas 
privilegiadas" (162) capaces de dar cuenta de una realidad, un fenómeno, un texto. Ginzburg propone una totalidad subterránea, pero no menos elocuente, cuya conformación depende más de la regularidad indicial y de la capacidad de irradiación de esos indicios para la producción de sentido. Esta vía me interesa también porque reserva un lugar especial a la intuición, la misma que los masones deben desplegar para interpretar sus símbolos.

Los principios de isotopía semántica continua y de regularidad indicial, sumados al conocimiento sobre sistemas y niveles de significación de la hermenéutica masónica, habilitarían una lectura del símbolo que, además de eludir el riesgo de sobreinterpretación, visibilice en la novela su grado de vaivén semiótico pertinente. En lo que sigue, pues, observo el funcionamiento de los símbolos entre el sistema semiótico masónico y el sistema semiótico de la novela. Este último releva el símbolo en tanto significante que integra solo uno de los códigos citados por Hijo de ladrón. Demostrar la relevancia de esta intertextualidad implica no solo dar cuenta de la serie de correspondencias que la legitima; también es necesario discutir sus aportes a la significación del texto o del proyecto literario en cuestión. Para enfatizar la reflexión sobre los sentidos que produce el intertexto y las funciones que cumple retomo lo que Kristeva llama trasposición de un sistema semiótico a otro ${ }^{5}$.

\section{UNA SINGULAR INICIACIÓN MASÓNICA}

En su sistematización antropológica del ritual de iniciación masónica, Raquel Barceló propone tres fases: separación o fase preliminal (muerte del profano, viaje a la tierra), margen o fase liminal (viajes y elementos simbólicos: aire, agua y fuego) y reagregación o fase postliminal (incorporación del recipiendario a la logia, en comunidad y entre masones). El ritual no aparece completo en ningún pasaje de la novela; lo que hace Rojas es partirlo en dos y ubicarlo en tres momentos de la narración. Es decir, hay un tratamiento

\footnotetext{
"the passage from one signifying system to another demands a new articulation of the thetic -of enunciative and denotative positionality. If one grants that every signifying practice is a field of transpositions of various signifying systems (an inter-textuality), one then understands that its "place" of enunciation and its denoted "object" are never single, complete, and identical to themselves, but always plural, shattered, capable of being tabulated. In this way polysemy can also be seen as the result of a semiotic polyvalence -an adherence to different sign systems" (Kristeva 60).
} 
modular de la ceremonia, que concuerda con el principio estructural del montaje, característico del relato de Hijo de ladrón y que Goić definió como una "concepción simultaneísta del tiempo" (131). Tal simultaneidad temporal mostrará una nueva faz en el análisis, facilitada por el principal núcleo aglutinador de símbolos de la masonería: la logia.

El índice que vincula a Hijo de ladrón con el ritual es su "componente vivencial" (Álvarez Lázaro 213), marcado por el involucramiento del neófito en una atmósfera inquietante, su sometimiento a circunstancias que le resultan ajenas y que le producen incomodidad, desorientación general y una sensación de peligro; es decir, el privilegio de una "percepción sensorial dirigida al cuerpo" (214). Es lo que sucede cuando Aniceto se enfrenta a la nieve en la cordillera, cuando se encuentra con el motín en Valparaíso y cuando ingresa al segundo calabozo en la misma ciudad (por motivos de espacio, abordaré solo los dos primeros). En los tres casos, la narración deriva un aprendizaje explícito o implícito; en los tres hay una retórica introspectiva y el lenguaje asume un talante metafórico; en los tres hay dominancia del narrador jovenprotagonista y de su experiencia "inmediatamente vivida" (Goić 127), pero cuya interpretación sugiere el narrador maduro-básico; en los tres, en fin, se desarrolla un proceso de conciencia alterada que linda con lo místico y que facilita ya sea el autoconocimiento de Aniceto, ya sea una integración entre aquel y una comunidad.

\section{De LA CORDILleRA A "LA TIERRA ESCONDIDA"}

La primera escena de la novela que remite a un simbolismo esotérico tiene lugar en la cordillera, cuando Aniceto trabaja como peón en las líneas del Ferrocarril Trasandino. La caracterización del espacio recuerda la de un templo masónico, un sitio alejado del mundo pero que lo representa, en virtud de la correspondencia microcosmos-macrocosmos, y en que se da una sociabilidad masculina: "Era un paisaje y un trabajo para hombres" (109). Desde un valle cordillerano por el lado argentino, pero con la perspectiva puesta en Chile -elocuentemente llamado "la tierra escondida" (103)-, el paisaje resulta:

estrecho en un sentido y amplio en dos: no había, valle abajo y por muchos kilómetros, obstáculo alguno para los ojos: los obstáculos estaban en las márgenes del valle, que bajaba encajonado entre enormes montañas [...] que lo detenían todo, todo menos la luz, el viento y la sombra inatajables. Y también era amplio en lo alto, en las montañas, más allá del cajón del río, contra el alto cielo, que 
parecía allí más alto que en ninguna parte, como si las montañas lo enaltecieran (115; énfasis míos).

El espacio físico de una logia, en efecto, forma un rectángulo cuyos costados largos son el norte y el sur, tal como el valle en que trabaja Aniceto, que cruza en forma perpendicular la cordillera. La caracterización de la altura y la profundidad del pasaje son precisamente las que el aprendiz masón debe conocer, según el catecismo interpretativo de su grado: la altura de la logia va desde la superficie de la tierra hasta lo más alto del cielo o cenit; su profundidad, desde la misma superficie hasta el centro de la tierra o nadir (Ariza 28-9). Las montañas que limitan el valle del Río de las Cuevas, donde trabaja Aniceto, semejan las columnas en que se instalan aprendices (al norte), compañeros y maestros (al sur). A nivel geográfico, el escenario cordillerano y el hecho de que la estación ferroviaria que casi pisa la frontera entre Chile y Argentina se llame Las Cuevas son datos coherentes con el imaginario masónico, pues antiguamente la iniciación se realizaba "en grutas naturales, después en criptas talladas en el flanco de las montañas" (Wirth $183)^{6}$. De hecho, la logia recrea el templo que mandó construir Salomón en la cima del monte Moriah, en Jerusalén (Moore 17), y simboliza tanto el mundo como el cosmos.

Todavía en la cordillera, Aniceto se enfrenta más tarde a la nieve, que le produce una sensación de aislamiento absoluto y de angustia. Lorena Amaro notó el carácter de frontera simbólica, de zona liminal que adopta aquí el espacio, facilitando una experiencia pedagógica y depuratoria. Ante la nieve se coronarían los despojamientos previos de la vida de Aniceto: de país, familia y especie (23-4). Coincido en general con este punto de vista. Ahora bien, la lectura de la escena junto a los otros textos indicados en la introducción permite precisar la experiencia del personaje e interpretarla en un sentido distinto.

El descenso de Aniceto por la cordillera reelabora la primera parte del ritual de iniciación masónico, que acontece en la cámara o gabinete de reflexiones. El viaje de la tierra, que consiste en la muerte del profano (hombre no masón) y el nacimiento del neófito, está señalada también en el MC1950, en que todo el capítulo en comento se titula "Valle de las calaveras" (en el gabinete

\footnotetext{
6 A menos que se indique lo contrario, las citas a Wirth son siempre del Libro del aprendiz.
} 
de reflexiones hay, de hecho, un cráneo humano representando la muerte) $)^{7}$. Antes de ingresar en esta tumba, el profano no solo se despoja de los roles, expectativas, valores y creencias que lo posicionan en el mundo profano (escena conocida como "despojamiento de los metales", lo que conecta con la observación de Amaro), sino que, en tanto el ritual figura una cosmogonía (Ariza 33), en esta fase el sujeto también regresa a un útero o matriz (Wirth 127). No es otra cosa lo que ocurre en la novela:

[M]e parecía que los lazos que hasta ese momento me unían al paisaje o al lugar en que me encontraba y me había encontrado antes, en todas partes, lazos de color, de movimiento, de fricción, de espacio, de tiempo, desaparecían dejándome abandonado en medio de una blancura sin límites y sin referencias, en la que todo se alejaba o se aislaba a su vez (118).

La soledad en que se encuentra Aniceto está dada por esta simultánea unión y desunión con todo lo que le rodea. La "blancura sin límites y sin referencias" imposibilita la existencia de forma alguna, pues para que haya forma deben existir contornos, bordes, límites. La angustia gatillada por la falta de individuación equipara soledad con ausencia de diferenciación. Lo indiferenciado es una de las cualidades del caos primigenio que se lee en los mitos cosmogónicos y que el ritual masónico fusiona con el descenso a los infiernos (Wirth 170). El absolutismo aterrador de la nieve reside en su capacidad para anular las coordenadas espaciales, pérdida de orientación que también afecta al recipiendario al ser privado de visión por una venda, que intenciona un proceso interior, propio de la conciencia (Álvarez Lázaro 214). La blancura agresiva de la nieve se opone solo en apariencia a la oscuridad

\footnotetext{
Con muy leves cambios, esta es la versión de este capítulo que Rojas publicó como "Páginas excluidas de Hijo de ladrón" en la revista Babel. Es la que se lee también en el mecanoescrito de 1951 (MC1951), el que, como informa Rojas a Silva Castro en una carta del 31 de marzo de 1955, pegada al inicio de este mecanoescrito, "sirvió de base para la publicación del libro" (s/p). Esto quiere decir que fue en la edición final que Rojas efectuó la drástica poda del capítulo... y aun así decidió publicar la frondosa versión por separado y en paralelo a la novela, en 1951. El movimiento, signado por la indecisión y la ambigüedad, pone al fragmento fuera de Hijo de ladrón pero al mismo tiempo lo inscribe en su órbita más íntima, casi como su doble reprimido.

Barceló bien lo grafica: "Si no fuera por la gravedad que le mantiene sujeto al suelo podría decirse que [el neófito] flota en el centro de una esfera y que ya no tiene derecha ni izquierda ni arriba ni abajo" (193).
} 
de la internación en la tierra (gabinete de reflexión), pues ambas coinciden en función. Ambas ciegan: "Dos o tres veces me he encontrado con ella en las montañas, solo yo y sola ella, durante horas, perdida la huella, borrados los rastros, sepultadas las señales, extraviados los caminos" (121). Como vengo comentando, la nieve es predeciblemente la amenaza de muerte: "este blanco que te persigue, te fatiga, te tapa los senderos, desfigura los caminos, oculta las señales y, además, te mete en el corazón el miedo a la soledad y la muerte" (121).

En "Significado de la Iniciación", Rojas aborda la transformación que produce el ritual en el hombre, analogando su situación en la logia a la de una semilla en la tierra. Esta analogía es tomada del evangelio de San Juan, central en el concepto de iniciación masónica:

En el evangelio de San Juan, podemos leer: "De cierto os digo que si el grano de trigo no cae en la tierra y muere, no dará fruto; mas si muriese, mucho fruto llevará" [...] En la iniciación masónica, tal vez más que en otras, se opera lo que podríamos llamar muerte y resurrección, o muerte, fecundación y nacimiento del alma de un ser, proceso que remeda maravillosamente el proceso que el grano de trigo u otra semilla cualquiera sufre al ser arrojada sobre la tierra. La muerte del iniciado es, en verdad, simbólica, aparente, pero aparente también es la de la semilla, y simbólica también, ya que simboliza la vida, o sea, la guarda en sí, la anuncia, la representa (86).

En el MC1950, por su parte, la escena de la nieve es bastante más extensa. Rojas podó de este capítulo todos los añadidos de carácter trascendentalista o esotérico y dejó tan solo breves comentarios a las observaciones sobre la dimensión física. Es decir, amputó la explicación de la metáfora material, una de las cuales justamente vincula, como en su ensayo masónico, hombre con simiente: "La semilla que duerme bajo la nieve está más segura que el hombre o que el animal que caminan sobre ella" (208). El hombre imita a la semilla en su búsqueda de bienestar. Aniceto desciende por la cordillera tal como el grano se hunde en la tierra para buscar la muerte, pero también para renacer, y renacer desnudo, libre de sus determinaciones previas. Prueba de ello es el surgimiento, en el pasaje del MC1950, de la oscuridad benefactora, esa que permite distinguir formas y que brinda un espacio habitable al hombre:

Mira ahora para adelante: todo está oscuro y negro y no se ve nada o casi nada y a pesar de eso sientes que esa negrura y esa oscuridad están llenas de rincones acogedores; hay arbustos y la 
tierra está seca; puedes tenderte en cualquier parte y no te mojarás ni te helarás; puedes hacer fuego con ramitas y calentarte, tomar café o simplemente mirar las llamas (209).

El acecho de la muerte y de lo indiferenciado es superado con el descenso en una oscuridad que marca además la diferenciación individual del personaje. Quien desciende recibe el cobijo de todos aquellos "rincones acogedores" donde puede descansar y reponer fuerzas. Este es, pues, el templo masónico al que el profano despierta luego de haber estado, como la semilla, dormido.

Significativamente, en este punto del MC1950 los compañeros de ruta comienzan a compartir experiencias, a contar historias relacionadas con el cruce de la cordillera y con sus trabajos y a aconsejar a Aniceto. Estas voces, que reflexionan sobre los valores humanos y las cualidades de la personalidad, enuncian alternativamente en primera y en segunda persona, pero también alternan y se confunden con el narrador básico (que está fuera del relato). Rojas es indeciso con su estatuto, lo mantiene en cierta ambigüedad enunciativa: en 1950 pone guiones a estos párrafos, dando la voz a los personajes, pero en Hijo de ladrón los elimina, a pesar de lo cual mantiene la marca en primera persona singular, en segunda singular y, por si fuera poco, en primera plural -"Miremos por última vez, muchachos" (123)-. Esta voz interior, que parece comunicarse directamente con la conciencia de Aniceto, empatiza con la circunstancia del protagonista, lo acompaña en el descenso, rememora y extrae conclusiones existenciales que expresa como consejos afectuosos de valor imperativo":

Miras para cualquier parte: no hay nada ni nadie que te pueda ayudar y la noche se acerca o la noche se alarga; hay una quietud mortal: nada se mueve, por lo menos nada que tú puedas ver; si gritas, nadie te oirá; si pides auxilio, nadie te socorrerá; debes confiar sólo en tus piernas y en tus pulmones; debes confiar, también, en tu presencia de ánimo, en tu valor, y a cada momento, a cada paso, te hundes en el silencio, en la quietud y en la soledad [...] No mires a lo lejos: debes mirar en qué punto vas a poner el pie en el siguiente paso y en el otro y en el otro (210; itálicas del original).

9 Goić escribió que la segunda persona es propia del narrador maduro, pero en este pasaje sigue punto por punto la experiencia del pasado inmediato del narrador joven. 
Las anónimas voces recuerdan a los consejos y al acompañamiento que aprovecha el recipiendario durante el ritual de iniciación ( $c f$. Barceló 189) ${ }^{10}$. El hermano guía lo introduce en el gabinete de reflexión y luego lo orienta a través de los viajes por el aire, el agua y el fuego. A nivel general y metafórico, tales consejos actúan como esos estímulos que recibe la semilla en la tierra: "pensamientos, sentimientos, virtudes, que son para él lo que las sales, los ácidos y los minerales son para la semilla" (Rojas, "Significado..." 86); todas ellas energías benéficas que recibe el neófito en el templo-tierra.

Al podar la mayor parte de estas voces e historias adyacentes, Rojas destaca el vínculo entre Aniceto y la voz guiadora, que acude a su experiencia personal para luego hablarle directamente; con ello se intensifica la experiencia del descenso, que se desarrolla en tiempo presente. Esta es la voz que Rojas asumía para dirigirse a los recién iniciados, en un discurso que ofreció numerosas veces como orador de su logia y que escuchó otras tantas. No solo el modo enunciativo (centrado en el $t u ́$ ) y el registro (a la vez tierno y exigente) de esa voz son asumidos por el narrador de la novela; también lo es el tema que aborda: la condición humana ${ }^{11}$. Justamente ese es el tópico de los pasajes de la nieve y de la herida ${ }^{12}$, en que el narrador maduro reflexiona y genera un tipo de conocimiento universalista a partir de una ilustración pedagógica que apela a las cualidades materiales y sensibles del mundo (e. g., la nieve, la oscuridad, el "cansancio de los metales", el nudo de pescador, etc.), consideradas como símbolos. En eso consiste la enseñanza interna de la masonería: tomar elementos de la esfera material para discurrir sobre la constitución intelectual y moral del mundo.

10 Durante la iniciación el neófito es acompañado por su hermano guía, designado por la logia para asistirlo en su formación, o por el experto, hermano que puede mejor socorrerlo en el trance iniciático (Álvarez Lázaro 208).

$11 \quad$ Botón de muestra de un discurso de Rojas: "los atributos y las virtudes, no son algo de que se goce o que se llegue a poseer por el solo hecho de recibirlos o de oír hablar de ellos: hay que ganarlos [...] no basta ser consagrado masón, ser llamado hermano por los masones y tener la libertad de llamar a ellos con el mismo nombre, así como no basta oír hablar de fraternidad para ser fraterno, de tolerancia para ser tolerante o de caridad para ser caritativo. Todo esto hay que conquistarlo, y su conquista, como la conquista de todo lo que es valioso y fundamental, exige trabajo, sacrificio, paciencia y a veces dolor" ("Discurso del Q. H. Orador").

12 Quizá la poda del capítulo se deba también a esta hermandad enunciativa y temática, que se extiende a la variante tipográfica (ambos están en itálicas). 
El descenso a Chile no solo significa, pues, un momento de afirmación/ conocimiento de sí mismo y de disponibilidad existencial (Aniceto convertido en una suerte de tabula rasa), sino que además vincula al personaje con una primera comunidad surgida en torno al trabajo común, con la que se reencontrará más adelante. Cuando ello ocurra, se retomará la pedagogía masónica.

\section{LOS TRES VIAJES DEL APRENDIZ ${ }^{13}$}

El capítulo IV de la segunda parte narra la experiencia de Aniceto en el motín popular por el alza en el precio de los tranvías, a poco de su arribo a Chile, tras la primera prisión. En el recuerdo lleva a su amigo, el vagabundo de las tortugas, que ha continuado un viaje en barco que él mismo querría hacer:

Doce nudos, catorce quizá, balanceándose de babor a estribor y cabeceando de popa a proa. Tenía a veces la sensación de que iba en su cubierta, frente al viento, aunque solo vagaba por las calles, al atardecer, con el alma como ausente o sumergida en algo aislante. En ese momento estalló la tormenta, sin que nadie supiera en qué callejuela del puerto, en qué avenida de la ciudad o en qué callejón de cerro ardió la chispa que llegó a convertirse en agitada llama. Me vi de pronto en medio de ella, indiferente a sus primeros relámpagos [...] (141).

La yuxtaposición de espacios (barco y calle) está dada por un término común: el viento que siente Aniceto, elemento ambiental que deriva luego en tormenta. Nótese que esta tormenta no acontece en el espacio físico del mundo novelesco, sino que es una metáfora de la revuelta. Lo importante es que la tormenta existe en la conciencia de Aniceto, quien además experimenta un vacío interior y se siente aislado, como ante la nieve. La conciencia del personaje alterna entre su imaginación sobre el viaje de su amigo y su propio presente en una avenida de Valparaíso, para decidirse al fin por este último. Con todo, la acción integra una permanente referencia al viaje, que debe ser entendido en un sentido esotérico. Producto del montaje espacial, Aniceto emprende una travesía espiritual rumbo al norte: "Me di vuelta, con la

13 Es cierto que antes he hablado de "viaje a la tierra", nombre correcto pero menos usual que el simple "gabinete de reflexiones". La doxa masónica reconoce que los viajes son por excelencia los tres que desarrollaré en esta sección. 
sensación de que me debatía por salir de un pantano formado por certificados y por barcos que navegaban hacia el cero de la rosa" (142; énfasis mío). Esta es la rosa de los vientos, cuyo grado cero o trescientos sesenta es el norte, la misma dirección que toma su amigo (Panamá, Nueva York y el Yukón, área glacial de Canadá).

El viento y el norte son precisamente las coordenadas del primer viaje ritual de la iniciación masónica, en que el neófito es purificado por el aire. Se trata del más arduo; el recipiendario encuentra distintos obstáculos que dificultan su avance (aquí, los certificados), cuya función es recordarle que toda empresa aislada, hecha puramente de recursos individuales y guiada por el triunfo es vana, egoísta y está condenada al fracaso (Wirth 72). Entonces vuelve a aparecer el hermano guía: Aniceto, perseguido por un policía a caballo que amenaza con matarlo, es salvado por el "hombre cuadrado" que antes, apenas iniciado el motín, le ha dado instrucciones, le ha dicho dónde ubicarse y luego lo ha felicitado -“¡Córrase, compañerito, ya vienen!” (145); “ßBravo, compañerito!” (146)-. En sintonía con la cita, el viaje masónico transcurre con pronunciado ruido ambiental, metáfora de una tormenta que desata "una violenta borrasca. El rayo crepita, el suelo tiembla y el granizo fatiga al imprudente que al fin es arrastrado por los torbellinos de un viento furioso y precipitado a través del espacio" (Wirth 72). Otro punto de sintonía entre el neófito y Aniceto es el énfasis de este último en su condición de extranjero que se ve envuelto en un proceso que no comprende. Tal como el candidato, Aniceto es el centro de la acción: los hombres comienzan a huir de la policía solo cuando él lo hace -"como si hubiesen esperado que lo hiciese primero" (146)-; el sonido de los cascos resuena "como para mí solo" (146).

En este pasaje, el símbolo del viento es reconocible sobre todo por su modo de intervención, es decir, no solo por su significación (sustantivo, sema), sino además por su performance (verbo, función) ${ }^{14}$. El viento cordillerano ha sido descrito como una fuerza vigorosa a la que los hombres temen por su capacidad de producir estragos - carpas voladas o aplastadas, cargamentos caídos, cuerpos humanos derribados o desnudados, frío extremo; en definitiva, la muerte-(104-6), aumentada por su invisibilidad. Aniceto observa que el viento absorbe la tierra-papeles, desperdicios y polvo sobre las rocas desaparecen

14 Michel Pastoureau, de quien tomo el concepto, llega a afirmar que "los símbolos medievales se caracterizan mucho más por su modo de intervención que por tal o cual significación" (23). 
“como absorbidos más que como desparramados" (106)-, verbo que retoma para indicar la desaparición repentina de los hombres que inician el motín: "de pronto desaparecen, vuelven y se van, llevados por alguna desconocida fuerza" (144); "el grupo de hombres desaparece como absorbido por una gran fuerza aspirante" (147). Lo interesante es que reserva el mismo modo de intervención y la misma analogía para la policía y el viento. Esta "mano invisible y fuerte, quizá demasiado fuerte" (106) que "zamarrea", "azota", "da latigazos", "deja tiritando" y "hace correr" a los hombres que marchan a su favor corresponde, pues, tanto a las fuerzas del orden público como a la potencia del aire: ambos producen estos fenómenos.

El segundo viaje se presenta casi condensado con el primero. Se trata de la purificación por el agua, elemento que obtiene en este pasaje una figuración doble. Por una parte, el agua del mar es el (engañosamente) placentero camino del vagabundo de las tortugas, vía ligada a las pasiones: "Panamá, Guayaquil, Callao, La Guayra, Arequipa, Honolulú, preciosos nombres, como de árboles o como de mujeres morenas. Es la primera vez que estoy junto al mar y siento que me llama, pareciéndome tan fácil viajar por él" (143; énfasis mío). El poder de seducción del mar, aumentado por ser la primera vez que Aniceto es afectado por él, será lavado con el agua de lluvia que es evocada ahora por una analogía auditiva: el galope de la caballería policial sobre los adoquines "recuerda el de gruesas gotas de lluvia golpeando sobre un techo de zinc [...] Sentí que perdía peso y que mi cerebro se limpiaba de ensueños y de recuerdos, quedando como en blanco" (144; énfasis mío). El sentido de este viaje según la doxa masónica obedece a una suerte de "bautismo filosófico que lava de toda impureza. Todas las fantasmagorías que falsean la imaginación deben ser arrancadas [...] El Iniciado debe también saber resistir a la atracción de las corrientes, a las que en la vida se abandonan las naturalezas vulgares" (73). Los dos sentidos del agua en el pasaje son también los que establece el libro masónico ${ }^{15}$.

La referencia al sonido ambiente del segundo viaje está dada también por el chocar de las espadas que efectúan los masones mientras se desarrolla la ceremonia; en Hijo de ladrón se lee: "el ruido de los cascos y el sonar de los metales se agrandaron hasta hacérseme insoportables" (146). La inquietud

15 Sin duda, el significado que obtiene el símbolo del mar en la novela es sobre todo el de libertad, apertura, incondicionalidad (Goić 136-7). Mi interpretación no cancela aquella, sino que sugiere una alternativa en este pasaje específico, pleno de guiños esotéricos. 
existencial que pivota este pasaje -"Quería elegir mi destino, no aceptar el que me dieran" (143) - comienza a resolverse en virtud de esta purificación de conciencia. Aniceto discierne y decide: "De nuevo quedo solo, pero ya no puedo volver a los certificados ni a los barcos ni al mar; debo quedarme entre los hombres" (144). Tal facultad de discernimiento es la que encontramos en el Libro del aprendiz: al neófito "[1]e corresponde en particular, pensar por sí mismo, sin esclavizarse a las opiniones de otros" (Wirth 73); en este caso, a la verdad o al deseo que el amigo de las tortugas descubre para sí. Aniceto no puede embarcar porque desea el deseo del otro. En el nivel denotativo el deseo de Aniceto resulta trunco - "trabajar y viajar, no trabajar y quedarme" (143)-, pero en el nivel connotativo se abre una tercera posibilidad en que nomadismo y sedentarismo pueden convivir, en virtud del puente que les tiende el trabajo. Si la lectura social evidente se decanta por el "trabajar y quedarme", una lectura desde la conciencia de Aniceto -y esto es lo que me interesa- puede reconocer que efectivamente se da un viaje, pero en un orden distinto, experiencial. Desde este plano, la antítesis física (mar/tierra) es irrelevante, pues el trabajo es el motor del cambio implicado en la experiencia (algo más sobre el trabajo en la próxima sección). Por otra parte, este es el único viaje posible para Aniceto. Quien viaja físicamente es su amigo, porque cuenta con "todo tal como lo quieren los funcionarios caras-de-archivadores: edad, sexo, domicilio, nacionalidad, todo certificado..." (142); es decir, se ubica en el lado del orden social y sus instituciones, que lo reconocen. El reconocimiento de Aniceto pasará por otro lugar.

El tercer viaje de la iniciación masónica corresponde a la purificación por el fuego y es el menos exigente: el "candidato impasible que avanza con paso firme, llega al término sano y salvo, después de haber estado tres veces envuelto en un manto de llamas" (Wirth 73). En concordancia con ello, después de su segunda carrera-viaje Aniceto avanza "despacio [...] dándome tiempo para recuperarme" (148), hasta llegar a "la cuadra en que me sorprendiera la carga de la caballería policial" (149). Nótese que esa cuadra corresponde a la misma avenida desde la que inició la huida; es decir, Aniceto ha descrito un círculo. Precisamente, en cada viaje el candidato da una vuelta completa a la logia y llega hasta el punto de partida, que sirve de centro. En la novela, este centro no es otro que el corazón del motín, que ahora se desarrolla con fuerza: "Las [calles] paralelas a la playa [...] estaban llenas de gente, sobre todo la avenida a que llegué, en donde ardía, en pleno fuego, la violenta llama" (149; énfasis mío). Esta "violenta llama" son las pasiones que el masón en parte ya controla: no lo queman, pero recibe de ellas un calor benéfico. Wirth explica el efecto de ello en el iniciado: 
Un ardor vivo, pero sabiamente gobernado, debe elevar al Iniciado, hacia todo lo que es noble y generoso. Le corresponde, más que nada, no dejar que jamás se extinga en su corazón el amor a sus semejantes. Una irradiación de simpatía se desprenderá así de él para rodearlo de una atmósfera saturada de benevolencia (132).

Después del volcamiento de un tranvía, los hombres comienzan a burlarse y a insultar a los policías, quienes observan sin capacidad de acción. Aniceto comenta: "Cada palabra de provocación y cada injuria dirigida hacia los policías me duelen de un modo extraño [...] Me parece que no debería injuriárseles ni provocárseles [...] la inconsciencia de los policías se me antoja forzosa, impuesta, disculpable por ello, en tanto que los gritos eran libres y voluntarios" (152). En Aniceto se gatilla una reflexión a partir de un dato sensible. La relativa ingenuidad que el lector pueda atribuir a este proceso bien encuentra su razón en una de las modificaciones de sí que opera el ritual en el neófito. El amor, en la forma de empatía, es lo que se reconoce en la cita de la novela, y es también lo que Aniceto perderá al ser testigo del abuso policial un poco más adelante. Al ser llevado enteramente por las pasiones, por la reacción sin premeditación, acaba equiparándose con un autómata al apedrear a un carabinero; desde el código que vengo revisando, se iguala con los ahora "deshumanizados" policías que proceden "mecánicamente" $(169)^{16}$.

\section{MALLETE Y CINCEL: ESCULPIR UNA COMUNIDAD}

Cito in extenso para comentar luego:

ya no eran cincuenta sino quinientos o mil quinientos los hombres $[\ldots]$ habían bajado quién sabe desde qué cerro [...] o quizá surgido de los talleres, del dique, de los barcos, de las chatas; algunos llevaban aún su saquillo con carbón o leña y se veía a varios con los pantalones a media pierna, mostrando blancos calzoncillos; otros iban descalzos [...]-iDémoslo vuelta! / Como no era posible quemarlos, la idea fue acogida con un rugido de aprobación [...] Alguien tomó el mando de

16 "Mecánicamente también, sin pensar en lo que hacía, terminadas todas mis reacciones mentales, me incliné, recogí una piedra y la lancé con todas mis fuerzas hacia uno de los policías" (169). 
la maniobra y su voz empezó a sonar como si se tratara de un trabajo normal. [...] La voz de mando sonaba con tal acento persuasivo, que resultaba difícil sustraerse a su llamado. [...] Me recordaba pasados días de duro trabajo y durante unos segundos sentí que no podría desprenderme del hechizo de la voz:-iAhora niñitos! / Sonaba como la voz de El Machete o como la de Antonio, El Choapino, y era la misma voz de siempre, la voz que ha construido las pirámides, levantado las catedrales, abierto los canales interoceánicos, perforado las cordilleras (Rojas, Hijo... 149-50; énfasis mío).

La cita muestra el surgimiento de una comunidad a la que diferentes hombres se suman progresivamente. Aniceto ha observado antes que "a juzgar por sus ropas eran obreros" (148), pero luego aparece esta multitud procedente de los más variados sitios de la ciudad, entre los que llaman la atención "los talleres" y el detalle exhibitivo de los "blancos calzoncillos". En jerga masónica, "taller" es otro nombre para "logia", donde los masones se visten con mandiles, símbolo tomado de la indumentaria albañil; el mandil del grado de aprendiz es, precisamente, blanco. Esta asociación por desplazamiento de significantes - no libre de parodia- obtiene continuidad en una imagen posterior, que figura a la comunidad de modo histórico. Cuando Rojas escribe que "era la misma voz de siempre, la voz que ha construido las pirámides, levantado las catedrales, abierto los canales interoceánicos, perforado las cordilleras", está citando explícitamente la historia de la masonería, cuyos orígenes la orden retrotrae a los gremios de picapedreros y constructores que levantaron las catedrales góticas del medioevo. De hecho, para caracterizar la diversidad de hombres que adhieren a la revuelta, el MC1950 acude también a los edificios cristianos: "morenos y bajos, altos y rubios [...] frentes pequeñas como de monos y altas como catedrales" (126). Por su parte, en el primer capítulo de las Constituciones (1723) de Anderson, libro que funda a la masonería especulativa o moderna, se afirma que los constructores de las pirámides no fueron otros que los masones (Anderson 5); esta tesis fue reforzada desde la primera mitad del siglo XIX, cuando la "egiptomanía" generó la incorporación de elementos y ritos egipcios al simbolismo masónico (García Arranz, "Simbología..." 75-6) ${ }^{17}$. 
Recuérdese que, a nivel de imaginario, es el oficio de constructor y todo su aparataje simbólico y ritual el que da cuerpo a las enseñanzas masónicas y a la autorrepresentación de sus miembros. La profundidad histórica que supone la inscripción de la acción motinesca, gracias a ciertos hitos constructivos, cumple una función doble: amplificar el movimiento del conjunto humano hasta darle un carácter épico ${ }^{18}$ y dotarlo de un sentido edificante (noble, dignificador) con un claro matiz civilizatorio y universalista. Más aún, el narrador maduro continúa la línea cronológica al sumar hitos posteriores, que llegan al presente mismo de la narración e incluso -y esto es lo más interesante- alcanzan la biografía de Aniceto: después de los canales interoceánicos (canal de Panamá) se mencionan los túneles cordilleranos, en referencia a los trabajos del Ferrocarril Trasandino, con lo que Aniceto se vuelve parte de ese conjunto humano. El efecto de lectura de una experiencia totalizante se logra por la gran cercanía entre narrador maduro y narrador joven. El puente lo ha insinuado el primero y lo ha retomado el segundo, quien también se comprende como parte de una gesta -"me recordaba pasados días de duro trabajo"-, pero ya no a escala de la Historia de la humanidad (con mayúscula), sino a escala cotidiana -"como si se tratara de un trabajo normal"-.

\section{PedAgogía Y DisYUnCIÓN POLÍTICO-IDEOLÓGICA}

La doble perspectiva de la narración habilita tanto la experimentación como la comprensión del acontecimiento, a semejanza de lo que ocurre en el ritual de iniciación. Luego de los tres viajes, al neófito le es removida la venda de los ojos y se le muestra un tapiz dispuesto al centro de la logia, que despliega los símbolos de su grado. La pedagogía consiste en la contemplación de los

vivir, de un plazo de dos o tres mil años" (140); cuando el motín ha terminado, hay una larga descripción de un "milenario cauce", que "estaba ahí quizá si desde que la tierra sudamericana se levantó del fondo de los mares o desde que el gran trozo de materia que hoy forma la luna fue arrebatado a nuestro planeta, dejando en él el hueco que el Pacífico se apresuró a llenar" (162); junto al cauce, Aniceto come un pescado para recuperar fuerzas, comida que simboliza su libertad y que engulle "aun en el caso de que se me hubiese probado que la pescada era originaria del Mar Rojo, y contemporánea de Jonás” (168). En estos fragmentos la temporalidad cubre desde tiempos bíblicos hasta geológicos, mientras que el espacio físico se ensancha hasta abarcar el cosmos (citas y breve análisis al final).

18 Me refiero a la magnitud del movimiento extrínseco o físico, característico de la epopeya. Recuérdese, por ejemplo, cuando en el canto IX de la Odisea el cíclope Polifemo lanza rocas al barco de Odiseo, afectando su dirección ( $c f$. Ramos 89). 
símbolos y en un comentario que dinamiza y relaciona sus sentidos, por lo general a cargo del venerable maestro (García Arranz, Simbolismo... 255). Como el candidato, Aniceto está prendido de una voz hechizante mientras contempla impresionado lo que se desarrolla ante sus ojos: el volcamiento de un tranvía a manos de la multitud. No es entonces que Aniceto no participe del motín - ¿Por qué estaba uno allí de pie, con las manos en los bolsillos o la espalda, en vez de unirse al esfuerzo común?” (150)-; participa, pero con la mirada y con el pensamiento.

En conjunto, la instancia narrativa conforma de manera más evidente un recurso narrativo que ya se había estrenado en el pasaje de la herida: se dispone una escena de instrucción cuyo destinatario es el lector, quien ahora debe interpretar el texto-tapiz recurriendo a su intuición ${ }^{19}$. De ahí que el narrador básico (voz magisterial) comente sobre el sentido global de la gesta, pero luego evite hacerlo acerca de otros cuatro símbolos (los que a su vez implican otros dos, apenas sugeridos). Por servir a la figuración de la comunidad, estos son idóneos para reflexionar sobre la axiología ideológico-política de la novela. El símbolo de la columna es el primero en surgir:

Junto con empezar a inclinarse el tranvía empezaba a erguirse el griterío, que se iniciaba con voces aisladas, restallantes, estimuladoras, a las cuales se unían pronto otras de admiración,formando todas, al fin, una columna que alcanzaba su mayor altura cuando el tranvía, imponente, pero bruto, indiferente a su destino, obedecía al impulso y cedía cinco, diez, quince grados: uno más y caería (151; énfasis mío).

La columna es un símbolo clave de la masonería, que la toma como signo de fortaleza y solidez (García Arranz, Simbolismo... 176), y que recuerda aquellas que el arquitecto Hiram instaló en el porche del templo de Salomón. Es interesante que sean dos columnas y que sus énfasis diverjan: la del grado de aprendiz se vincula con el elemento del fuego y es roja, mientras que la del compañero es blanca y remite a las nubes. De aquí se sigue un correlato moral: el fuego enfatiza la fuerza, mientras que las nubes el "sabio discernimiento" (Wirth, El libro del compañero 21). Con todo, ambas se asocian directamente

19 En sintonía con esto, Román Soto afirmó que el aprendizaje de Aniceto prefigura el del lector (270), pero empleó las historias narradas para demostrarlo. 
con la potencia divina, pues sus inscripciones ${ }^{20}$ indican la protección de dios hacia el pueblo elegido (Mackey 362).

¿De qué elemento es la columna del motín? Pensada como continuación de la llama, se trataría de la columna de fuego que guiaba por las noches al pueblo de Israel por el desierto, lo que finalmente la liga con la estrella flamígera ( $c f$. Snoek 324). Esta, el símbolo más característico del grado de compañero ${ }^{21}$,"representa el espíritu que anima al universo, el principio de toda sabiduría y el poder generador de la naturaleza", y es emblema "del genio que eleva al hombre y le impulsa a las grandes acciones, símbolo de ese fuego sagrado, de ese destello de luz divina con que el GADU [Gran Arquitecto del Universo] creó nuestras almas" (Frau Abrines 294). El masón debe convertirse en ella para irradiar su potencia sobre el mundo (Wirth, El libro del compañero 32), ser un "astro humano" (63). Esta figuración recuerda la del "astro rei" con que cierta poesía ácrata de orientación modernista pensaba al hombre revolucionario y al incendio anarquista. Al igual que la estrella flamígera (y las columnas), la luz y el incendio ácratas participan de una retórica divina; y a la inversa, la llama participa del imaginario anarquista y del masónico: en la novela es al mismo tiempo luz generadora de toda vida e incendio vengativo que anuncia la aurora redentora de los explotados del mundo ${ }^{22}$. Esta lectura bi-isotópica (en lenguaje de Greimas) puede extenderse

20 La columna del aprendiz lleva inscrita la letra B, del nombre "Boaz", que significa "en la fuerza será establecida"; la del compañero, la J, de "Jakin", que se traduce como "Dios establecerá su casa de Israel” (Mackey 361-2).

$21 \quad$ La alternancia de los simbolismos del grado de aprendiz y compañero en este capítulo es también visible en la insistencia de los números tres y cinco, que respectivamente los identifican: "veinte, treinta, cincuenta hombres me rodean, gritan y gesticulan" (143); "mis oídos se llenan con el rumor de diez, treinta, cincuenta o cien caballos" (144); "sólo veía en mí a alguien que se hallaba solo ante el trote largo de cincuenta animales de tropa" (145); "ya no eran cincuenta sino quinientos o mil quinientos los hombres que llenaban la cuadra" (149); "no se trataba ya de veinte o de cincuenta hombres, sino de centenares" (151). La misma clave numérica se observa en el capítulo que narra su segunda estadía en un calabozo. La estrella flamígera tiene, por último, cinco puntas y se conoce también como el pentalfa pitagórico.

22 Lo mismo es aplicable al símbolo de la tormenta. Tómense, por ejemplo, los versos de Luis Olea: "Con sombrío crespón, cubrióse el cielo / de negro i rojo... / Son las chispas quemantes de ese fuego / que enciende los enojos" ("Sobre las ruinas 19-20); o de Escobar y Carvallo: "Yo soi un astro de incendiario fuego, / un soplo que disgrega i eslabona. [...] Camino hacia el Pais de las auroras / en medio de las bravas muchedumbres!" ("Profesion de fe!" 36). El mismo Rojas hizo suyo este símbolo en "Gritos de combate" (1912): "Como 
a todo el pasaje, pero sigue en buena medida lo que la literatura anarquista ya había inaugurado ${ }^{23}$.

Lo que me interesa $-\mathrm{y}$ lo que resulta más provechoso para la comprensión del proyecto rojiano- no es argumentar un caso más de "vino viejo en odres nuevos". El simbolismo masónico continúa solo hasta cierto punto lo que el simbolismo ácrata había iniciado, pero también abre un espacio distinto, y es en el interín entre uno y otro que la significación de la comunidad oscila, produciendo sentidos nuevos y enriqueciendo el núcleo ético-político de su representación. Reexaminaré su valor semiótico en la novela.

En principio, la revuelta está marcada semióticamente por la horizontalidad, como una fluida marea de miembros humanos: "La muchedumbre fluctuaba como una ola, moviéndose nerviosamente; rostros, cuerpos, piernas, brazos" (149); "el motín bullía" (153). Frente a ella, la columna de voces se alza -"empezaba a erguirse el griterío"- como una sola. A la idea de horizontalidad (asociada al eje sintagmático, contigüidad metonímica), típica de la fuerza obrero-anarquista, se enfrenta entonces una de verticalidad (propia del eje paradigmático, reemplazo metafórico $)^{24}$. El par ola/columna tiene un valor complementario, en tanto figuraciones sucesivas que obtiene la fuerza popular ${ }^{25}$; así considerada la imagen es nuevamente total.

Con todo, vale la pena retener la diferencia entre ambas, pues la columna y el trabajo mancomunado logran lo que la muchedumbre heterogénea no puede: volcar el tranvía, acabar con el símbolo de la usura social. La ola aporta en la destrucción del tranvía, pero luego continúa actuando en la forma

Goethe gritamos ¡Luz, más luz! y alumbramos con la tea e incendiando al mismo tiempo, lo viejo, lo carcomido, lo que ya huele a cadáver. Destruimos. Y destruirán” [sic] (19).

23 La columna aparece contadas veces en la poesía y el teatro anarquistas, pero cuando lo hace indica la multitud en huelga. Se recordará también la importancia de la pieza teatral de Alberto Ghiraldo, La columna de fuego (1913), en que el fuego es el amor. Por lo demás, la columna parece ajena al vocabulario rojiano; en textos de juventud no la menciona.

$24 \quad$ La columna reemplaza los pendones y banderas, típicos símbolos verticales de la poesía ácrata. En los escritos tempranos de Rojas, la fuerza popular es siempre horizontal: al igual que la multitud del motín, en "Gritos de combate" (1912) es "ola que ataca" (19). Como las voces de la columna, en "Visión roja" (1913) hay un rumor -"Rumor de parto, clamoroso y terrible, que anuncia el nacer de la fuerza" (23)- que continúa en gritos, pero esos gritos no obtienen figuración alguna. Los dos símbolos verticales que remiten a la masonería - "columna" y "catedrales"- son hápax de la novela.

25 Sigo el principio que Álvarez y Massmann derivaron de los cuentos de Rojas: el valor axiológico de la levedad, entendida como capacidad de transformación. 
del saqueo a los almacenes ubicados en las cuadras aledañas a la del motín, que pasan a llenarse de gente, tal como el agua rellena un espacio vacío. Para dar el golpe de gracia al tranvía es preciso el discernimiento (columna blanca), y es entonces que surge el "trabajo normal", la voz conductora y las referencias a la masonería. A diferencia de la ola, la columna se construye. Este símbolo ingresa al imaginario rojiano no solo para complementar la fuerza popular horizontal, sino además para expresar la distancia política que media entre narrador maduro y narrador joven. La narración sugiere, pues, complementariedad semiótica en la representación de la comunidad, pero privilegia la verticalidad para dar cuenta de la efectividad de la acción política. Esto implica posar una duda sobre el incendio anarquista de antaño y alzar un símbolo nuevo, que remite a una modalidad representacional del sujeto político más tradicional, unitaria y jerárquica: ya no es dispersión sino compactación. Y, con todo, la columna está compuesta por un sinfín de voces, de estibadores, jornaleros, vendedores callejeros, empleados y obreros (154), composición que obliga a mantener abierto su sentido al mismo tiempo que su índice semiótico establece una lógica y no otra.

Una oposición afín se replica en otros dos símbolos, ahora con una valencia moral más clara. Volcado el tranvía, se da un enfrentamiento entre dos grupos que el narrador distingue claramente: el proletariado y el lumpen, tal como lo planteó el marxismo clásico. El líder obrero es el mismo que ha ayudado a Aniceto en uno de los viajes iniciáticos:

[A]pareció de nuevo el hombre cuadrado, cuadrado de cuerpo, cuadrado de manos, cuadrado de cara, un hombretón formidable, como hecho de una sola y gruesa viga que tuviera varios y apretados nudos y que capitaneaba una banda de obreros que se enfrentó de pronto a otra banda, una de aquellas de procedencia subterránea (156).

Como contraparte del trabajador se encuentra el líder de los rateros, quien "daba la impresión de un cuchillo mellado y lleno de orín o sebo, pero peligroso. El hombre con aspecto de herramienta de carpintero se acercó a él y le gritó" (157) con una voz tan imponente como la que volcó el tranvía. De ahí en adelante el narrador pasa a identificarlos como "hombre-mazo", "hombre cuadrado" u "hombre-herramienta", quien merece la admiración del joven Aniceto; y "hombre cuchillo", que más bien le repulsa. Lo interesante es que cuando el cuadrado increpa al cuchillo por robar en medio de la revuelta (por su falta de conciencia), su grito se convierte en un "chaparrón" verbal: su voz, "llena, fuerte, recorría al otro hombre de arriba abajo, por sus parches y roturas, su grasa y sus jirones" (158). 
En este contexto, que ha comenzado con claras alusiones a la masonería, es coherente leer el par mazo/cuchillo como analogía de las dos herramientas que caracterizan al grado de aprendiz: mallete (o mazo) y cincel, con las que el neófito comienza el trabajo sobre sí mismo, principal labor durante toda su vida en el taller. Entiendo, pues, que el chaparrón verbal es realmente un golpe del mallete al cincel ${ }^{26}$. En relación con este, el principal significado del mallete es la voluntad activa, consciente: "le simboliza al masón su potencial para estimular su conducta, impulsándola hacia un destino previamente autodecretado" (Herrera 47); en función del mallete, el cincel representa "el pensamiento determinado, la resolución tomada" (Wirth 164) o, una vez más, el discernimiento (García Arranz, Simbolismo... 127). Constituyen así un par complementario que nos retrotrae a su desempeño como herramientas; cada uno posee un valor en sentido activo-pasivo. Juntos percuten el camino hacia el progreso individual y social (Pike 30).

Así es como también los considera el narrador básico: "El uno era cuadrado y duro; el otro, afilado y resbaladizo: habría cabido por donde no habría podido caber el otro, quien, a su vez, habría podido echar abajo lo que el otro no habría podido sujetar" (158-9). Sin embargo, después del martillazoilustración se invierten los roles y otro hombre-cuchillo apuñala al mazo proletario en la cabeza. El cincel se rebela contra el mallete, y es entonces que

26 En Chile hubo dos periódicos obreros llamados El Martillo: en Valparaíso (1898) y en Antofagasta (1913). Sin embargo, la literatura ácrata de la época casi no tematiza los símbolos del martillo y el cincel (o buril, escoplo) -excepción es la prosa poética de Rojas, "Orfebres", en que los anarquistas trabajan con "buriles mágicos [que] pulen el oro sucio de las conciencias" (44)-. Las pocas veces que figura el primero, su contexto es herrero. Veamos dos poemas populares: "El himno al martillo", de Marcial Cabrera Guerra, aparecido en la compilación Poesías ácratas, que imprimió Policarpo Solís en 1904, y "El martillo" (1919), del argentino Ernesto Mario Barreda, canción para niños publicada por Ediciones Selectas América (que dirigía Samuel Glusberg) y que se imprimió en Chile en el Cancionero revolucionario (1925) de Armando Triviño. En el primero, el martillo es aliado de los rieles y de las rocas en los Andes (referencia al Ferrocarril Trasandino) y su fragua se interpreta como la lengua más antigua del mundo, la del "hombre primero": "- - es un himno que brota en el éter / i desciende vibrante a la tierra, / entonando al través del espacio / el hosanna del arte i la ciencia" (41). En el segundo, el martillo forja conciencias y hombres: "Fibras del hierro que se moldea, / Almas ardidas de un hondo afán: / Que a golpes mágicos labra la idea / Y entre las almas vibrando van..." (Barreda 22). El registro de ambos es, pues, de un espiritualismo modernista (con un filo esotérico en Cabrera Guerra). Es de notar además que estos poemas no fueron escritos por escritores ácratas, sino que el carácter ecléctico del anarquismo facilitó su ingreso en aquel repertorio literario. 
la multitud se dispersa, que la fuerza del motín decae. El hombre-cuchillo, puramente animal e inconsciente, arruina la ruta del progreso. Rojas adapta este simbolismo no solo para reflexionar sobre las problemáticas relaciones entre subgrupos populares, sino también para reconocer que incluso el lumpen, aunque resistido, ocupa un lugar en la sociedad y que ese lugar es potencialmente constructivo ${ }^{27}$. Los hombres-cuchillo poseen una destreza, algo también se puede aprender de ellos. Aniceto retiene aspectos tanto del cuadrado como de la línea: le gusta el trabajo, pero también el vagabundeo. Con todo, el mismo narrador maduro sanciona el sentido de la acción total: "no quedaba gran cosa que hacer y no había por qué hacer más; no se trataba de una revolución" (160). El mal empleo de las herramientas imposibilita escalar en el significado político de la revuelta. El mazo debe golpear al cincel. El motín ya no es la revolución.

\section{PIEDRAS CÓSMICAS: FILIACIÓN Y COMUNIDAD}

Tanto la gesta del motín como el simbolismo del hombre-mazo inscriben a Aniceto en una filiación, y con esto llego a los dos últimos símbolos que anuncié. El mallete y el cincel son entregados al aprendiz para que comience el proceso de desbastamiento de la piedra bruta (sí mismo), piedra irregular y áspera que debe convertirse en piedra cúbica mediante el pulimiento de sus imperfecciones (ignorancia, prejuicios, vicios, mezquindad, etc.). Mazo y cincel son sostenidos además por el compañero masón, quien ha progresado en el camino del perfeccionamiento intelectual y moral de sí y quien entonces puede acoplarse a un trabajo conjunto: se ha convertido en una de las piedras para construir el templo de Salomón (García Arranz, Simbolismo... 133-6). El desbastamiento representa, pues, "la formación del individuo en vista del exacto cumplimiento de su misión humanitaria y social" (Wirth 178).

27 Ya en el cuento "Canto y baile" (1929) se opone un grupo de ladrones con conciencia social a la "palomilla" o lumpen, identificada también con el cuchillo. El indicio vinculante es aquí la ropa: recuérdese la vestimenta impecable del Gallego y los demás ladrones frente a los jirones que caracterizan a los hombres-cuchillo. En último término, este indicio comunica al Gallego con el primer cuento en que Rojas echa mano del simbolismo esotérico, "El hombre de la rosa" ( $c f$. Linker). El brujo que protagoniza el relato es también ladrón y viste limpiamente (23). Es decir, el vínculo del ladrón con lo oculto no es nuevo, pero el par proletariado-mazo / lumpen-cuchillo y la reflexión del narrador al respecto son propios de Hijo de ladrón. 
Estos valores, transmitidos por la forma cúbica de la piedra-hombre trabajada y por la cuadratura del hombre-mazo refieren no solo a los obreros, sino que se extienden además al padre de Aniceto: "era siempre el hombre delgado, alto, blanco, de bigote canoso, grandes cejas, rostro un poco cuadrado y expresión adusta y bondadosa" (41). El Gallego también es reconocido como "sobrio, tranquilo, económico y muy serio en sus asuntos; de no haber sido ladrón habría podido ser elegido, entre muchos, como el tipo del trabajador con que sueñan los burgueses y los marxistas de todo el mundo" (30). Su movimiento se da en la forma de una levitación que no conoce obstáculos y que está envuelta en un halo mágico: abre las puertas "con la sola aproximación de las manos, como si entre el frío metal y los tibios dedos existiera alguna oculta atracción" (31); suele aparecer "de pronto, como surgiendo de la noche o del aire, mágicamente" (32). Desde este punto de vista, en un nivel connotativo, la filiación de Aniceto con el mundo del robo no es ya mancha que lavar, sino una filiación subterránea y mítica que señala una potencia y que remite a la masonería y al código cultural del simbolismo esotérico en general. Para mostrar el nuevo sentido de esta filiación comentaré otro pasaje.

El narrador socialmente integrado ( $c f$. Álvarez) de Hijo de ladrón moviliza este código en la forma de analogías hiperbólicas que buscan producir un efecto de humor en el lector. Este humor no debería soslayar, sin embargo, la connotación de estos pasajes, que contribuye efectivamente a delinear la tensión ideológica que atraviesa la instancia narrativa. Durante su segunda prisión, Aniceto observa que: "El Gallego era allí tan desconocido como Flammarion" (219). ¿Cómo interpretar este chiste? Camille Flammarion fue el mayor difusor de la astronomía a fines del siglo XIX y un reputado espiritista, muy admirado por los masones por proponer un deísmo que desafiaba el de la religión católica ( $c f$. Álvarez Lázaro 241-2). Además, era leído en los círculos obreros chilenos desde el siglo XIX ( $c f$. Muñoz 104-5), lo que quiere decir que el lector de la novela, en 1951, sí lo conoce. La analogía entre Flammarion y el Gallego pivota sobre un atributo "desconocido", un sentido de lo oculto que hermana oficios en otro sentido distantes. Astronomía y robo se superponen: el éxito de ambas prácticas reside en una precisión excepcional ( $c f$. Rojas, Hijo... 30), que les permite acceder a lo no aparente (el cosmos, la casa de algún desprevenido). Arte del robo y arte de la astronomía se vuelven uno solo en virtud del Arte Real masónico, cuya brújula es la geometría, ciencia sagrada, conocimiento secreto que se habría trasmitido desde tiempos antediluvianos hasta la Inglaterra del siglo XVIII. La orden considera la geometría como la base no solo del arte de la 
construcción, sino de las siete artes liberales del medioevo, entre las que se cuenta, por supuesto, la astronomía ${ }^{28}$. Astrónomos, magos, brujos y obreros (en sentido medieval: arquitectos, carpinteros, artesanos, albañiles) son todos nombres que designan a los masones. Otro tanto se puede decir de El Gallego y Flammarion, obreros que participan de la magia, el misterio y el secreto.

Esto nos lleva a otro pasaje, en que se asocian las cualidades revisadas en El Gallego a los trabajadores portuarios. Aniceto los observa anhelante y admirado, impedido como está de trabajar debido a su herida:

[G]rupos de hombres que esperan se les llame a cargar o descargar, a limpiar o a remachar, a aceitar o a engrasar, a arbolar o a desarbolar, a pintar, enmaderar o raspar, pues ellos pueden enmaderar y raspar, pintar, desarbolar o arbolar, engrasar o aceitar, remachar y limpiar, cargar y descargar el universo entero, con estrellas, soles, planetas, constelaciones y nebulosas, con solo pagarles un salario que les permita no morirse de hambre y proporcionarles los medios de llegar al sitio necesario; insistentes y pequeños hombrecillos, constructores de puertos y de embarcaciones ${ }^{29}$, extractores de salitre y de carbón [...] (130; énfasis mío).

Como en el chiste revisado, aquí la diferencia de escala es nuevamente abismal y su clave se halla en el imaginario masónico: los hombres trabajan en albañilería y en el orden cósmico indistintamente, pues lo que manejan (y lo que calla la cita) es nuevamente la geometría. La estructura especular de la enumeración verbal ("cargar o descargar, a limpiar o a remachar [...] remachar y limpiar, cargar y descargar”) enfatiza la igualación de escalas y proyecta todas las capacidades indicadas por los verbos al trabajo con los planetas, estrellas, etc. El cambio en la conjunción -alternativa ("o") por

28 Este amplio campo semántico se delinea ya en las Constituciones de Anderson, que incluyen un recuento de la legendaria historia de la orden. La geometría sería el conocimiento que funda a la masonería y a la arquitectura, en virtud de un método de leyes de proporción tomado de las artes mecánicas (2). Si el relato de la novela disloca esa geometría con su desorden e incoherencia, el registro reflexivo se nutre de ella. El narrador maduro ha alcanzado en el plano existencial el mismo conocimiento que El Gallego demuestra en el mundo físico -recuérdese su trabajo con cerraduras, llaves y candados ( $c f$. Rojas, Hijo... 31) y que Aniceto maduro caracteriza el robo como un oficio liberal, que requiere virtuosismo (255-6)-, lo que nos devuelve a la primera parte de este ensayo. Es el paso de la masonería operativa a la especulativa.

29 En MC1950 y MC1951 se lee "catedrales" $(112 ; 109)$ en lugar de "embarcaciones". 
conjuntiva ("y")- aumenta la potencia del trabajo en ese plano superior, al reunir lo que antes permanecía separado o ambiguo. Es cierto que Aniceto no acaba integrándose a esta comunidad en la novela, pero sí rescata de ella su fraternidad y libertad. Sobre todo, lo vincula con ella una voluntad y un deseo de trabajo (que crea el mundo... iy el cosmos!). En última instancia, esto resignifica el sentido de aquel en el texto: no se trata solo del trabajo de los obreros o de una ética protestante del trabajo, sino de un elemento que informa la axiología de la novela al pensarla en relación con la formación del propio sujeto y de la comunidad. De este modo, se retoma una comprensión masónica del trabajo, pero también se la pone en tensión al hacerla exceder el marco moral que guía su interpretación por parte de la orden, la que en último término responde a su carácter constitucionalista, estatista y liberal (cf. Pike; García Valenzuela 115). El trabajo sobre sí mismo y la moral auténtica, parece decir Rojas, rebasa esos moldes y desconoce sus estrecheces leguleyas.

Con esto vuelvo a la piedra. La ecléctica filiación del Gallego es reivindicada en términos tanto de autoconocimiento como de diferenciación con la comunidad que Aniceto forma junto a Cristián y el Filósofo:

Sentía, sin embargo -tal vez lo deseaba-, que no llegaría jamás al estado de Cristián -ya era imposible- y que no me quedaría en el de El Filósofo. Advertía en mí algo que no había en ellos, un ímpetu o una inquietud que no tenía dirección ni destino, pero que me impediría aceptar para siempre solo lo que la casualidad quisiera darme. Quizá si debía eso a mi padre. En ocasiones, la misma fuerza puede servir para obrar en varias direcciones; todo está en saber utilizarla (347-8).

La referencia al padre funciona ahora como el discernimiento-cincel que en definitiva deja ver el credo meliorista del Aniceto maduro, fuente de ese hálito de esperanza que respira Hijo de ladrón y uno de los principios que guía la moral progresista de la masonería. Según aquel, "la bondad absoluta del mundo es el término final necesario de su perfectibilidad" (García Valenzuela 107). De ahí que los grados de aprendiz, compañero y maestro puedan leerse como una grilla que sirvió a Rojas para pensar el trío comunitario, aun cuando la correspondencia sea solo aproximada.

Sin duda, el Filósofo aparece como símbolo de cierta sabiduría o experiencia adquirida, pero esta es limitada: todavía no es un ser autónomo, pues vive al día y depende de lo que el azar quiera entregarle. Por otra parte, Cristián casi no pertenece a la especie humana. Se lo compara con un animal y con los hombres de las alcantarillas. El Filósofo cuenta haberlo conocido "muy 
hombre ya, mineralizado hasta un punto difícil de apreciar" (338, énfasis nuestro). Su falta de capacidades sociales se expresa también en su mirada dura, en su "tan duro" (347) núcleo; la vida "lo ha endurecido" (338). Otro índice para comprender la condición de Cristián está en el final de MC1950, distinto al de Hijo de ladrón. Este último muestra a Aniceto y al Filósofo partiendo al trabajo; tras dudarlo, Cristián se suma a la pareja. En MC1950 se lee, en cambio:

Aquello, sin embargo, terminaría pronto: veinte pasos más y llegaríamos al punto en que el camino doblaba; allí perderíamos de vista a Cristián y al conventillo.

— ¡Bruto! — exclamó de pronto Echeverría, estirando los brazos y cerrando los puños. Parecía insultar a alguien.

El grito llegó cuando aún quedaban algunos pasos:

— ¡Espérenme!

Era un grito como de desgarramiento; algo se rompía en Cristián (326; énfasis mío).

La rigidez de Cristián es literalmente la de la piedra bruta (como el tranvía, "bruto, indiferente a su destino"), pero él es, al mismo tiempo, menos que un aprendiz. Cristián está condenado a permanecer en calidad de piedra bruta, sin entrar en el lenguaje (se comunica por medio de monosílabos), en la reflexión. La rotura o desgarro vocal prefigura su muerte, al ser sorprendido "cuando quería abrir una puerta o una ventana" (Sombras contra el muro 11), las mismas que Echeverría y Aniceto, respectivamente, desean pintar al final de Hijo de ladrón. Cristián no cuenta con las herramientas para trabajarse: "Si le das un pincel, un martillo o una llave inglesa, no sabrá qué hacer con ellos, no sabrá manejarlos" (Hijo... 338) ) $^{30}$-el hombre-cuchillo al menos sabe moverse, es ágil y astuto-- De ahí que, aun cuando Rojas le tiende una mano al darle agencia (en la novela es Cristián quien toma la iniciativa de unirse al dúo), sea muy pronto excluido de la comunidad. Por contraste, el Filósofo ha llegado a cierto saber porque le gusta "escarbar en el hombre" (337), con lo que se insiste en el trabajo con la materia como metáfora del sí mismo. Aniceto, por último, ha logrado entrar en el lenguaje (narra su historia al Filósofo) y ha alcanzado un conocimiento acerca de sus límites y de su

30 Bien dijo López que Cristián es “un héroe que está imposibilitado para alcanzar un conocimiento de sí" (304). 
relación con el mundo; sobre todo, tiene un "ímpetu" o "inquietud", esto es, una potencia de la que puede disponer con inteligencia. Sabe también que llegará a un "estado" superior al del Filósofo. Por último, el Aniceto joven tiene ya conciencia de una jerarquía antropológica basada en la posesión de potencias sensibles y morales -jerarquía que la narración muestra en el trío comunitario-. Ya ha comenzado a esculpirse.

\section{CIERRE DE LOS TRABAJOS}

El aporte del simbolismo masónico a Hijo de ladrón es muy significativo: abre una perspectiva que complejiza la significación ético-moral y políticoideológica de pasajes fundamentales en que se elaboran representaciones del sujeto y de la comunidad. En ocasiones, Rojas acude al simbolismo para conectar con la axiología del ideario masónico o con su esquema antropológico; otras veces, emplea tan solo su estructura y trastoca aquel sentido o bien lo adapta. Las diversas implicaciones de esta intertextualidad permiten precisar la filiación de lo que se ha observado como "una antropología vagamente humanista o existencialista" (Álvarez 116) en Hijo de ladrón y en el proyecto general de Rojas. Más que pensar esa antropología como una actualización de posibilidades ya contenidas en el lenguaje ácrata, creo que es posible hablar de un discurso masónico que ostenta un peso específico en el texto y cuyo hipotético impacto en el resto de la tetralogía está por estudiarse. El simbolismo de ese discurso, que se encuentra y se desencuentra con el anarquista en virtud de un eclecticismo congénito a ambos, aporta a la dilucidación de lo que Soto llamó la gran "ambigüedad axiológica, inestabilidad, plurivalencia y dinamismo" (273) de la significación novelesca. El símbolo creado por Rojas se juega en este vaivén, espectro de sonido que presta el tono ideológico -ya resuelto, ya tenso- a la narración.

La estructura que abarca la mayoría de las funciones que cumple el simbolismo masónico en el texto es la del ritual de iniciación. Este se configura como un cronotopo mítico, unidad espacio-temporal que sobredetermina el sentido de experiencias clave en la formación de Aniceto y en la generación de comunidad. De ahí el amplio radio de la intertextualidad masónica, que afecta no solo al nivel de la representación, sino también al de la estructura enunciativa. La disposición del ritual de iniciación genera una máxima cercanía entre el narrador maduro y el joven, y de aquí deriva la experiencia totalizante que trasmite la instancia narrativa; esto es, no solo del discurrir 
ontologizante y del presente absoluto que caracterizan al narrador maduro (cf. Goić), sino además de la yuxtaposición de planos narrativos propia del montaje. Sería provechoso pensar este aprendizaje simbólico (que procede ante todo por imágenes) junto a ese que extrae Aniceto de las historias que le son narradas ( $c f$. López; Soto).

Hay consenso en que la obra rojiana representa un mundo articulado por un humanismo popular y masculino (Concha, "Los primeros cuentos..." 340), base para la formación de una comunidad contraburguesa (López), dotada de un sentido premoderno y romantizado de la relación social (Rojo 228-9) y cuyos miembros resisten a la proletarización y disciplinamiento de sus espacios vitales (Ubilla). Estos juicios enfatizan el rechazo hacia los discursos y lógicas de los procesos de modernización, a la vez que afirman la proyección literaria de un espacio alternativo, que escapa a los modos de subjetivación capitalistas. A la luz de lo presentado, se puede añadir que el proyecto de Rojas también dialoga con e integra una vertiente de pensamiento ilustrado y humanista más bien tradicional, que no disimula el sentido normativo de una idea de autoridad moral cuyo concepto del trabajo es de fuerte impronta meliorista. Es cierto que algunos de estos elementos eran parte ya del ambiente anarquista en que Rojas se había formado, pero su reencuentro con ellos en la masonería les otorgó nuevos sentidos y un estatuto existencial al interior de una estructura determinada. La comprensión rojiana del sujeto y de la comunidad es también informada por la reinterpretación de un núcleo de pensamiento socialmente integrado.

El concepto masónico del trabajo nutre en buena medida la Bildung del sujeto y de la comunidad en la novela (ya sea en la cordillera, en el motín, a través de la filiación obrero-masónica de Aniceto o con el Filósofo y Cristián). Ahora bien, la interpretación rojiana lo desembaraza de su vínculo con la ética protestante, propia del capitalismo, para presentarlo como una afección que aumenta la potencia de quienes participan en él. Es la organización de la multitud en un "trabajo normal" la que da efectividad a su acción política y la hace partícipe de una dimensión revolucionaria; es el trabajo de Aniceto sobre sí mismo el que le permite disponer de una potencia transformadora de su perspectiva sobre su destino y sobre el mundo. Escribo "multitud" y "afección", conceptos spinozistas, para proyectar un diálogo con la reflexión de Braulio Rojas y Patricio Landaeta sobre la comunidad rojiana entendida como transindividual. Esta multitud es plural, no totalizable y escapa a la lógica de la institucionalidad política, pero su potencia aumenta al organizarse en torno a una acción cohesionante que es asistida por la razón ( $c f$. Espinosa Antón 192-5); de otro modo, se debilita 
al ser llevada por afectos pasivos, como la ola pasional del motín o como el actuar "mecánico" de Aniceto. El simbolismo masónico muestra que esa razón está teñida por una idea de jerarquía que es necesario reflexionar para comprender el proyecto de Rojas.

\section{BIBLIOGRAFÍA}

Adriasola, Juan José. "Manuel Rojas, lector. Para abrir una discusión en torno a su programa intelectual". Revista de Humanidades 40 (2019): 11-39.

Álvarez, Ignacio. "El diagrama de un nuevo pacto". Novela y nación en el siglo XX chileno. Ficción literaria e identidad. Santiago: Universidad Alberto Hurtado, 2009. 95-139.

Álvarez, Ignacio y Stefanie Massmann. "Vínculo social e identidad en la primera narrativa de Manuel Rojas”. Estudios filológicos 27 (2011): 7-21.

Álvarez Lázaro, Pedro. La masonería, escuela de formación del ciudadano. $4^{\mathrm{a}}$ ed. España: Universidad Pontificia Comillas, 2012 [1996].

Amaro, Lorena. "Pasadores de fronteras: Manuel Rojas y José Santos González Vera". Chasqui 44.2 (2015): 20-32.

Anderson, James. The Constitutions of the Free-Masons. New York: Jno. W. Leonard and Co., Masonic Publishers, 1855 [1723].

Ariza, Francisco. La masonería. Símbolos y ritos. Zaragoza: Libros del Innombrable, 2007.

Barceló, Raquel. "La iniciación, un rito de paso en la masonería: la muerte simbólica". Ritos de paso: arqueología y antropología de las religiones, Vol. III. Coords. Patricia Fournier, Carlos Mondragón y Walburga Wiesheu. México: Instituto Nacional de Antropología e Historia/Escuela Nacional de Antropología e Historia, 2009. 185-204.

Barreda, Ernesto Mario. Canciones para los niños. Buenos Aires: Ediciones Selectas América, 1919.

Barthes, Roland. S/Z. Trad. Nicolás Rosa. Buenos Aires: Siglo XXI, 2004.

Cabrera Guerra, Marcial. "El himno del martillo". Poesías ácratas, vol. II. Comp. Policarpo Solís Rojas. Santiago: Imp. León Víctor Caldera, 1904. 41-42.

Concha, Edmundo. "Entrevista a Manuel Rojas". Conversaciones con Manuel Rojas. Entrevistas 1928-1972. Comp. Daniel Fuenzalida. Santiago: Zig-Zag, 2012. 39-44.

Concha, Jaime. "Los primeros cuentos de Manuel Rojas". Manuel Rojas. Estudios críticos. Selecc. Naín Nómez y Emmanuel Tornés. Santiago: Universidad de Santiago, 2005. 333-351.

Concha Ferreccio, Pablo. "Manuel Rojas, masón: primeras entradas de lectura". Manuel Rojas: una oscura y radiante vida. Nuevas lecturas y aproximaciones críticas. Eds. María José Barros y Pía Gutiérrez. Santiago: Ediciones Universidad Católica de Chile, 2020. 283-309.

Eco, Umberto. "La sobreinterpretación de textos". Interpretación y sobreinterpretación. Trad. Juan Gabriel López Guix. España: Cambridge University Press, 1997. 56-79. 
Escobar y Carvallo, Alejandro. “Profesion de fe!”. Poesías ácratas, vol. I. Comp. Policarpo Solís Rojas. Santiago: Imprenta Internacional, 1904. 36-37.

Espinosa Antón, Francisco Javier. "Los individuos en la multitud”. Revista Co-herencia 15.28 (2018): 183-207.

Frau Abrines, Lorenzo. Diccionario enciclopédico de la masonería, vol I. La Habana: La Propaganda Literaria, [1891?].

García Arranz, José Julio. "Simbología masónica o los emblemas del autoconocimiento". Palabras, símbolos, emblemas. Las estructuras gráficas de la representación. Eds. Ana Martínez Pereira, Inmaculada Osuna y Víctor Infantes. Madrid: Turpin Editores/Sociedad Española de Emblemática, 2013. 59-94.

Simbolismo masónico. Historia, fuentes e iconografia. Bilbao: Sans Soleil Ediciones, 2017.

García Valenzuela, René. Introducción a la historia de la francmasonería en Chile. $2^{\mathrm{a}}$ ed. Santiago: Ediciones de la Gran Logia de Chile, 1997 [1991].

Ginzburg, Carlo. "Indicios. Raíces de un paradigma de inferencias indiciales". Mitos, emblemas, indicios. Morfología e historia. Barcelona: Gedisa, 1999 [1986]. 138-175.

González Vera, José Santos. "Manuel Rojas". Algunos. 2a ed. Santiago: Nascimento, 1967. 213-243.

Goić, Cedomil. La novela chilena. Los mitos degradados. $3^{\mathrm{a}}$ ed. Santiago: Universitaria, 1971 [1968].

Grez, Sergio. Los anarquistas y el movimiento obrero. La alborada de "la Idea" en Chile, 1893-1915. Santiago: Lom Ediciones, 2007.

Herrera Michel, Iván. Las herramientas masónicas. Oviedo: Ediciones del Arte Real, 2013.

Kristeva, Julia. Revolution in Poetic Language. Trad. Margaret Waller. New York: Columbia University Press, 1984.

Linker, Susan. "A collision of rationalism and spiritualism in 'El hombre de la rosa' of Manuel Rojas: decoding the secret signals". Hispanic Review 68.1 (2000): 21-36.

Logia “Germinación" N 81. Plancha $1^{\text {er }}$ Gr., $N^{\circ} 3,24$ de marzo de 1944. Archivo de la Gran Logia de Chile.

López, Berta. "El aprendizaje de Aniceto Hevia". Manuel Rojas. Estudios críticos. Selecc. Naín Nómez y Emmanuel Tornés. Santiago: Editorial Universidad de Santiago, 2005. 287-317.

Mackey, Albert G. Lexicon and History of Freemasonry. Philadelphia: McClure Publishing, 1909.

Martín, Luis. "Las logias masónicas. Una sociabilidad pluriformal”. Hispania 214: 523-549.

Moore, William. Masonic Temples. Freemasonry, Ritual Architecture, and Masculine Archetypes. Knoxville: The University of Tennessee Press, 2006.

Muñoz, Yerko. "¡Vuelven los muertos!: espiritismo y espiritistas en Chile (1880-1920)". Seminario de grado, Licenciatura en Historia. Universidad de Chile, 2012.

Olea, Luis. "Sobre las ruinas". Poesías ácratas, vol. II. Comp. Policarpo Solís Rojas. Santiago: Imp. León Víctor Caldera, 1904. 19-20.

Pastoureau, Michel. Una historia simbólica de la Edad Media occidental. Trad. Julia Bucci. Buenos Aires: Katz, 2006. 
Pike, Albert. Morals and Dogma of the Ancient and Accepted Scottish Rite of Freemasonry. New York: Masonic Publishing Company, 1874 [1871].

Rojas Castro, Braulio y Patricio Landaeta Mardones. "Literatura, afectos y conatus. Delimitaciones conceptuales para una teoría literaria desde el punto de vista de la potencia". Modernos \& Contemporáneos 2.4 (2018): 54-70.

Ramos, Óscar Gerardo. Categorías de la epopeya. Bogotá: Instituto Caro y Cuervo, 1988.

Rojas, Manuel. "Gritos de combate”. Un joven en la batalla. Comp. Jorge Guerra. Santiago: Lom Ediciones, 2012 [1912]. 19.

"Visión roja". Un joven en la batalla. Comp. Jorge Guerra. Santiago: Lom Ediciones, 2012 [1913]. 23-24.

“Canto y baile”. Travesía (novelas breves). Santiago: Nascimento, 1934 [1929]. 57-77. "El espíritu revolucionario en nuestros pueblos". Babel 3 (1939 [1936]): 77-78. “Significado de la Iniciación”. Revista Masónica de Chile 2-3 (1946): 86-87. “Discurso del Q. H. Orador". 23 de julio de 1947. Archivo de la Gran Logia de Chile. Tiempo irremediable. Mecanoescrito inédito. 1950. Biblioteca Nacional de Chile. Archivo del escritor. 000858731. http://www.memoriachilena.gob.cl/602/w3article-348589.html.

Tiempo irremediable. Mecanoescrito inédito. 1951. Biblioteca Nacional de Chile. 000909215. http://www.memoriachilena.gob.cl/602/w3-article-341634.html.

Hijo de ladrón. Edición establecida por David Barrera, Diego Leiva, Alejandra Caballero e Ignacio Álvarez. Santiago: Tajamar Editores, 2018 [1951].

“Algo sobre Hijo de ladrón". Hijo de ladrón. Santiago: Tajamar Editores, 2018 [1951]. 361-390.

Rojo, Grínor. "La contrabildungsroman de Manuel Rojas". Las novelas de formación chilenas. Santiago: Sangría, 2014. 165-266.

Sánchez Ferré, Pere. "La iconografía masónica y sus fuentes”. REHMLAC 6.1 (2014): 55-76.

Snoek, Jan. "Masonic rituals of initiation". Handbook of Freemasonry. Eds. Henrik Bogdan y Jan Snoek. Leiden/Boston: Brill, 2014. 321-327.

Soto, Román. "Hijo de ladrón: subversión del mundo y aprendizaje transgresivo". Manuel Rojas. Estudios críticos. Selecc. Naín Nómez y Emmanuel Tornés. Santiago: Universidad de Santiago, 2005. 267-285.

Ubilla, Lorena. "Sujetos marginales en la narrativa de Manuel Rojas. De prácticas y discursos de disciplinamiento a focos de tensión con el modelo modernizador". Revista Chilena de Literatura 77 (2010).

Wirth, Oswald. El libro del aprendiz. Manual de instrucción iniciática editado para el uso de los francmasones del primer grado. Santiago: Imprenta Macarter, 1995 [1894].

El libro del compañero. Manual de instrucción iniciática editado para el uso de los francmasones del segundo grado. Biblioteca Upasika, www.upasika.com. [1894]. 